\title{
MENURUNKAN PERILAKU MEMBOLOS DENGAN TEKNIK KONTRAK PERILAKU DI SMA NEGERI 2 SANGATTA UTARA
}

\author{
Edy Purwanto \\ SMA Negeri 2 Sangatta Utara
}

\begin{abstract}
ABSTRAK
Penelitian ini bertujuan untuk memberikan suatu upaya sistematis, objektif, logis dan berkelanjutan serta terprogram yang dilakukan oleh konselor atau guru bimbingan dan konseling untuk memfasilitasi perkembangan peserta didik/konseli untuk mencapai kemandirian dalam kehidupannya. Selanjutnya disebutkan tujuan daripada layanan bimbingan dan konseling adalah untuk membantu konseli mencapai perkembangan optimal dan kemandirian secara utuh dalam aspek pribadi, belajar, sosial dan karir.
\end{abstract}

Kata Kunci: perilaku membolos, kontrak perilaku

\section{PENDAHULUAN}

Keberhasilan pelayanan bimbingan dan konseling dapat dilihat dari perubahan perilaku yang ditunjukan oleh siswa ke arah yang lebih positif, salah satu contoh perubahan perilaku yang diharapkan adalah berkurangnya perilaku membolos di sekolah. Perilaku membolos secara umum dapat diartikan sebagai perilaku siswa yang tidak masuk sekolah dengan alasan yang tidak tepat atau ketidakhadiran siswa tanpa alasan yang jelas. Pada akhirnya membolos menjadi fenomena yang menghambat proses pembelajaran dan apabila masalah ini tidak segera ditangani secara serius maka dikhawatirkan banyak hal negatif yang muncul sebagai dampak dari perilaku tersebut.

Saat ini tidak sedikit ditemukan siswa di tingkat jenjang pendidikan menengah Atas (SMA) yang memiliki perilaku membolos. Hal ini memang bukanlah hal yang baru lagi, perilaku membolos di jadikan sebagai sebuah jawaban atas kejenuhan yang sering dialami oleh siswa dalam kegiatan pembelajaran di sekolah. Alasan lainnya karena kuatnya pengaruh teman sebaya daripada orang tua atau guru, mereka lebih mendengarkan ajakan temannya meskipun hal itu belum tentu baik bagi dirinya akan tetapi peserta didik yang membolos tersebut tidak mampu menolak ajakan teman lain dan juga tidak mampu menyatakan tidak atas setiap ajakan atau ancaman dari teman. Hal lain yang menyebabkan perilaku membolos adalah tidak menyukai guru atau pelajaran tertentu di sekolah,sedang ada permasalahan baik itu di sekolah ataupun dirumah yang ingin dihindari atau kurangnya perhatian dan bimbingan sehingga dia berusaha mencari perhatian dari hal lainnya yaitu pertemanan.

Perilaku tersebut salah satunya ditemukan pada siswa di SMA Negeri 2 Sangatta Utara. Berdasarkan observasi awal yang dilakukan oleh penulis, di temukan bahwa ada beberapa siswa yang memiliki perilaku membolos. Adapun perilaku membolos yang di lakukan para siswa tersebut yakni sering tidak mengikuti proses pembelajaran di dalam kelas tanpa keterangan yang jelas, meminta izin ke luar kelas tapi tidak kembali lagi ke kelas, serta tidak masuk kelas setelah jam istirahat usai. Bila perilaku membolos ini dibiarkan terus menerus dan tidak segera ditindak lanjuti, maka orang tua dan guru di sekolah tentu juga ikut menanggung akibat dari perilaku tersebut.

Peneltiian ini mendeskripsikan apakah layanan konseling individual teknik behavioural contract dapat mengurangi 
Jurnal Inovasi BK, Volume 2, Nomor 2 Desember 2020 perilaku membolos peserta didik SMA Negeri 2 Sangatta Utara.

Hasil Penelitian Ana Malichah (2016 : 160), Pengaruh Layanan Konseling Kelompok dengan Teknik Behavior Contract Terhadap Pengurangan Perilaku Membolos pada Siswa Kelas XII SMK Negeri 4 Semarang Tahun Ajaran 2016/2017" menyimpulkan bahwa konseling kelompok dengan teknik behavior contract berpengaruh positif terhadap pengurangan perilaku membolos siswa kelas XII SMK Negeri 4 Semarang Tahun Ajaran 2016/2017.

Selanjutnya penelitian yang dilakukan oleh Wanda Esa Adi Wibowo (2013) "Upaya Mengatasi Perilaku Membolos Sekolah Melalui Konseling Individual Dengan Pendekatan Behavior Teknik Kontrak Perilaku (Penanganan Kasus Pada Siswa SMP Negeri 4 Rembang)". Penelitian ini berdasarkan fenomena yang terjadi di SMP Negeri 4 Rembang yang menunjukkan banyak siswa melakukan pelanggaran maupun tata tertib sekolah khususnya siswa yang mempunyai perilaku membolos sekolah. Hasil penelitian menunjukkan bahwa ketiga konseli sebelum dilakukan 18 konseling memiliki perilaku membolos sekolah. AAR membolos sekolah karena guru galak, jenuh dengan pelajaran, takut disuruh maju untuk mengerjakan soal dan ajakan teman. DE membolos sekolah karena membantu orang tua bekerja, guru galak jenuh dengan pelajaran, dan ajakan teman. YM membolos sekolah karena guru galak dan suka mengejek, takut disuruh maju untuk mengerjakan soal, dan ajakan teman. Setelah diberikan layanan konseling individual dengan pendekatan behavior teknik kontrak perilaku, konseli AAR, DE dan YM mulai bisa memahami pentingnya sekolah, kenapa guru galak kepadanya dan konseli juga berusaha menolak ajakan teman untuk membolos sekolah. Kesimpulan konseling secara keseluruhan pada konseli AAR, DE dan YM yang mempunyai perilaku membolos sekolah dapat diatasi melalui konseling individual dengan pendekatan behavior teknik kontrak perilaku. Terbukti adanya perubahan perilaku berupa penurunan membolos sekolah.

Disisi lain pada penelitian terdahulu dikatakan bahwa layanan konseling individual dengan teknik behavior contract dapat dijadikan sebagai strategi intervensi untuk mengurangi perilaku membolos siswa. Keterkaitan penelitian di atas dengan penelitian yang akan dilakukan oleh peneliti adalah penelitian ini dapat menguatkan dan melengkapi penelitian sebelumnya.

Peneltiian ini bertujuan untuk mendeskripsikan Tujuan penelitian ini adalah untuk mengetahui pengaruh konseling individual teknik behavioural contract terhadap pengurangan perilaku membolos peserta didik SMA Negeri 2 Sangatta Utara.

\section{METODE}

Penelitian ini bergerak pada area bimbingan pengembangan pribadi dengan menggunakan layanan konseling individual. Penelitian ini dilaksanakan dalam dua tahap ( 2 siklus). Tiap siklus dilaksanakan satu kali kegiatan sesuai dengan indikator perubahan tingkah laku yang hendak dicapai. Hasil tiap siklus dipergunakan untuk merefleksi langkah yang harus dilakukan berikutnya. Jadi dalam penelitian Tindakan kelas ini masingmasing siklus terdiri dari Perencanaan (Planning), Pelaksanaan (Action), Pengamatan (Observation), dan Refleksi (Reflection)

Pengambilan dua subjek penelitian ini didasarkan atas hasil rekap absensi siswa kelas X B dan X F selama satu semester. Dari hasil rekap absensi siswa yang diperoleh selama satu semester di kelas X B dan $X$ F tersebut, terdapat siswa yang mempunyai kebiasaan membolos sekolah, diantaranya JV dan F. Setelah diketahui siswa tersebut benar-benar mempunyai masalah kebiasaan membolos sekolah, 
siswa tersebut kemudian dijadikan subjek penelitian, yang kemudian akan diberikan perlakuan (treatment) secara individual dengan pendekatan behavior teknik kontrak perilaku.

Dalam penelitian ini, metode yang digunakan oleh peneliti yaitu observasi, wawancara serta dokumentasi. Pedoman observasi yang digunakan dalam penelitian ini adalah dengan menggunakan check list (daftar cek) dimaksudkan untuk mensistematikan catatan observasi. "Check list adalah suatu daftar yang berisi namanama subyek dan faktor-faktor yang hendak diteliti" (Hadi, 2004: 170). Check list lebih menjamin bahwa peneliti mencatat tiap-tiap kejadian yang betapapun kecilnya tetapi telah dipandang penting dan telah ditetapkan hendak diteliti. Observasi dalam penelitian perilaku membolos sekolah, peneliti melibatkan dua siswa kelas X B dan $\mathrm{X}$ F sebagai konseli yang mempunyai kebiasaan membolos sekolah, dua siswa tersebut diantaranya (JV dan F).

Wawancara merupakan metode pengambilan data dengan cara menanyakan sesuatu kepada seseorang yang menjadi informan atau responden secara tatap muka (Afifuddin, 2009: 131). Jenis wawancara yang dilakukan yaitu dengan pendekatan menggunakan petunjuk umum wawancara yang dilakukan secara mendalam (deep interview). Karena dalam penelitian ini wawancara berguna mengungkap secara mendalam tentang perilaku membolos sekolah yang dialami oleh kedua siswa kelas X SMA Negeri 2 Sangatta Utara yaitu (JV dan F). Wawancara yang dilakukan peneliti untuk mendapatkan data awal yaitu dengan mewawancarai orang-orang yang berada disekitar subjek penelitian dan subjek penelitian itu sendiri

Dalam penelitian ini, jenis dokumentasi yang digunakan oleh peneliti yaitu dokumen pribadi. Dokumen pribadi merupakan catatan atau karangan seseorang secara tertulis tentang tindakan, pengalaman, dan kepercayaan. Jenis dokumen pribadi yang digunakan untuk memperoleh keterangan informasi dalam penelitian ini yaitu berupa data absensi siswa. Peneliti juga menggunakan dokumentasi dikarenakan peneliti merasa bahwa dokumentasi yang berupa absensi siswa akan sangat membantu dan menambah keakuratan data yang diperoleh di lapangan.

\section{HASIL DAN PEMBAHASAN}

Hasil penelitian ini akan memaparkan bagaimana gambaran perilaku membolos sekolah dan menangani kasus perilaku membolos sekolah melalui konseling individual dengan pendekatan behavior contract. Sebelum melaksanakan konseling, terlebih dahulu dilaksanakan seleksi subyek. Subyek penelitian diperoleh berdasarkan hasil wawancara awal dengan wali kelas dan juga hasil rekap absensi siswa tersebut selama satu semester. Kemudian dari hasil seleksi subjek penelitian tersebut, diperoleh dua subyek penelitian yang mempunyai masalah mengenai perilaku membolos sekolah. Adapun kedua subyek penelitian yang memiliki perilaku membolos sekolah diantaranya JV dan F.

Penelitian Tindakan Bimbingan dan Konseling ini dilakukan terhadap dua orang peserta didik pada kelas $\mathrm{X}$ yang sering berperilaku membolos. Kedua peserta didik ini dipilih sebagai subjek penelitian dikarenakan tidak adanya perubahan yang berarti setelah guru BK dan wali kelas memberikan bimbingan dan arahan terhadap perilaku membolos keduanya. Sehingga setelah didapatkan latar belakang permasalahannya penulis merasa perlu kiranya diterapkan salah satu Teknik konseling yang dapat membantu peserta didik dalam memahami diri, kelemahan dan kekurangannya yang menyebabkan mereka berperilaku membolos.

JV adalah anak ke 1 dari 2 bersaudara. Pekerjaan ayah sebagai supir 
Jurnal Inovasi BK, Volume 2, Nomor 2 Desember 2020 taksi online dan ibu sebagai ibu rumah tangga. JV bertempat tinggal di rumah kontrakan kecil yang sederhana di jl. Yos Sudarso. Secara sosial ekonomi peserta didik berasal dari keluarga menengah. Orang tuanya sebetulnya peduli dengan pendidikan anak-anaknya, menurut orang tua JV terlalu dini masuk sekolah yaitu pada usia 3 tahun sudah masuk sekolah playgroup. Sehingga pada usia sekarang mulai merasa jenuh atau bosan, dan ini mempengaruhi motivasi belajarnya.

Berdasarkan hasil wawancara awal yang didapat dari konseli JV wali kelas, konseli diketahui bahwa perilaku membolos yang dilakukan konseli yaitu tidak masuk sekolah hingga berhari-hari. Penulis mendapatkan data bahwa sejak tahun ajaran baru 2018/2019 pada awal tahun kenaikan peserta didik di kelas X, peserta didik sudah ada data ketidakhadiran tanpa keterangan di bulan Agustus sebanyak 9x alpa.

Penulis dan wali kelas memberikan penanganan terhadap peserta didik dengan pemanggilan orang tua, berdasarkan hasil pertemuan dengan orang tua didapatkan hasil bahwa orang tua tidak mengetahui anaknya tidak ke sekolah tanpa keterangan karena setiap hari selalu pergi ke sekolah dan pulang sekolah seperti jadwal sekolah. Selain upaya konsultasi dengan orang tua, dilakukan juga layanan home visit serta konseling individu dengan peserta didik. Setelah dilakukan layanan koseling individu beberapa kali dengan peserta didik, diketahuilah alasan peserta didik bolos sekolah. JV mengaku bolos sekolah karena keinginan sendiri tanpa ada paksaan atau ajakan dari pihak luar. Hal ini dilakukan salah satu nya karena untuk menghindari pelajaran atau tugas yang belum terselesaikan untuk hari itu. Adapun tempat yang dituju untuk membolos adalah warnet atau rental PS dan rumah teman nya yang sudah pulang sekolah.

Siswa (F) adalah anak tunggal. Tinggal dengan nenek dan kakek serta saudara sepupu. Ibu kandung sudah meninggal dunia sejak F masih bayi. Ayah tinggal dan bekerja di Sulawesi. Ayah sudah menikah lagi sejak $F$ masih kecil, dan sempat dibawa ke Sulawesi dan tinggal dengan ibu tiri nya. Karena pola pengasuhan dari ibu tirinya yang kurang baik, maka $\mathrm{F}$ di bawa dan di rawat oleh neneknya di Sangatta sampai sekarang. Kondisi ekonomi $\mathrm{F}$ termasuk yang kurang mampu, nenek dan kakeknya tidak lagi bisa bekerja karena keadaan fiisk nya yang kurang kuat dan sering sakit-sakitan. Untuk biaya sehari-hari dan sekolah $\mathrm{F}$ harus menunggu kiriman uang dari ayahnya. Lingkungan tempat tinggal $\mathrm{F}$ terletak di gang kecil belakang SMAN 2 Sangatta dengan lingkungan pergaulan yang kurang kondusif.

Banyak faktor yang mempengaruhi motivasi belajar $\mathrm{F}$, sehingga menyebabkan kebiasaan F untuk bolos sekolah. Berdasarkan pengamatan penulis, $\mathrm{F}$ memiliki data ketidakhadiran tanpa keterangan sebanyak 6x dari awal tahun pelajaran (Agustus). Dari data yang dikumpulkan diperoleh informasi bahwa hal ini merupakan perilaku berulang dari kelas VII. F memiliki kecenderungan mudah dipengaruhi oleh temannya, hal ini diperburuk dengan keadaan di lingkungan pertemanan di rumahnya yang merupakan peserta didik yang juga memiliki kebiasaan membolos, dan ada juga teman nya yang putus sekolah. Tempat $\mathrm{F}$ membolos adalah rumah temannya yang juga bolos sekolah. Setelah beberapa kali dilakukan konseling individu, konsultasi orang tua dan juga home visit, penulis merasa perlu membangun kesadaran peserta didik akan perilakunya yang merugikan masa depannya tersebut.

Pada siklus I, JV menyatakan ada keinginan untuk tidak membolos tetapi karena ada ketakutan tugas mata pelajaran belum di kerjakan maka terpikirkan untuk membolos ke tempat rental PS. Setelah diberikan Teknik behavioural contract, JV menyatakan akan berusaha untuk 
mengurangi tingkat membolosnya dengan cara mengatur waktu untuk dapat mengerjakan tugas-tugas sekolah sehingga tidak ada alasan bolos untuk meghindari tugas yang belum dikerjakan di rumah.

Adapun F mengaku membolos karena ada kesempatan dimana temanteman nya melakukan hal yang sama. Mereka membolos bersama di rumah salah satu temannya. Setelah diberikan Teknik behavioural contract, F merasa lebih memiliki kesadaran akan perilakunya yang dirasa banyak merugikannya dibandingkan menguntungkannya.

Pada Siklus II, JV menyadari bahwa perilaku nya membolos sangat merugikan dirinya terlebih karena untuk menghindari atau belum menyelesaikan tugas mata pelajaran tertentu. JV menyadari pula atas kesalahannya melarikan permasalahannya dirumah kepada hal yang justru berdampak negatif bagi dirinya. Sedangkan, F mengaku dengan penuh kesadaran menyesali perbuatannya dalam membolos dan memiliki keinginan untuk berubah lebih baik.

\section{KESIMPULAN}

Konseling dengan Teknik behavioural contract memberikan bantuan kepada peserta didik untuk dapat mengatasi masalah yang dihadapi nya di sekolah. Dengan memberikan Teknik behavioural kontrak peserta didik dapat mengubah perilaku nya yang tidak adaptif menjadi adaptif dan untuk memotivasi adanya perubahan perilaku sehingga diperlukan kondisi yang mengikat untuk tercapai perilaku yang diinginkan.

\section{DAFTAR PUSTAKA}

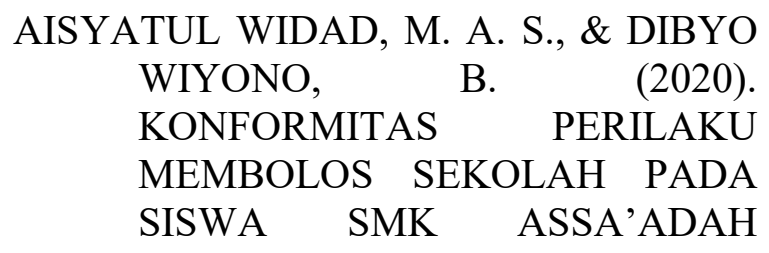

BUNGAH GRESIK. Jurnal BK UNESA, 11(4).

Alwahbi, A. (2020). The use of contingency contracting in educational settings: A review of the literature. Educational Research and Reviews, 15(6), 327-335.

Anyamene, A. P., Anyachebelu, F. E., \& Ngozi, A. (2017). Effects of Individualized Counselling Technique on Remedying Truancy Among Junior Secondary School Students. Journal of Guidance, 1(1), 15-19.

ARDIYANTI, M., \& INDAH PRATIWI, T. (2018). Studi Tentang Penanganan Perilaku Membolos Peserta Didik oleh Konselor Sekolah di SMP Negeri Se Kecamatan Kerektuban. Jurnal BK UNESA, 8(2).

Aziz, R. (2018). Peranan Kecerdasan Emosional terhadap penyesuaian diri dan perilaku delinkuen pada remaja di Yogyakarta. ULUL ALBAB Jurnal Studi Islam, 3(1), 83-98.

Badriah, L. (2018). Persepsi Peserta Didik Terhadap Guru Bimbingan dan Konseling di Madrasah Aliyah Ali Maksum. At-Tajdid: Jurnal Ilmu Tarbiyah, 7(1), 16-30.

Basa, M. J. M. (2014). BOTTLENECKS AFFECTING PROFESSIONAL PRACTICE AMONG FILIPINO ARCHITECTS CROSSING ASEAN BORDERS: A REVIEW. PEMBANGUNAN SOSIAL DALAM MENGHADAPI MASYARAKAT EKONOMI ASEN, 5, 316.

Bee Sanna, J. (2018). Penerapan Konseling Kelompok Teknik Kontrak Perilaku untuk Meningkatkan Perilaku Tanggung Jawab Pribadi Siswa Kelas Viii-f SMP Negeri 34 Surabaya. Jurnal BK UNESA, 8(1).

Chalimi, M. K. (2017). Implementasi Teknik Behavior Contract untuk 
Jurnal Inovasi BK,Volume 2, Nomor 2 Desember 2020 Memotivasi Siswa dalam Penyelesaian Pekerjaan Rumah (PR) di Madrasah Tsanawiyah Negeri (MTsN) Pilangkenceng Madiun. Jurnal Intelektual: Jurnal Pendidikan Dan Studi Keislaman, 7(1), 82-89.

Clarke, M., \& Scurry, T. (2020). The role of the psychological contract in shaping graduate experiences: a study of public sector talent management programmes in the UK and Australia. The International Journal of Human Resource Management, 31(8), 965-991.

Erford, B. T. (2017). Orientation to the counseling profession: Advocacy, ethics, and essential professional foundations. Pearson.

Erlina, N., \& Fitri, L. A. (2016). Penggunaan Layanan Konseling Individu dengan Pendekatan Behavioral untuk Mengurangi Prilaku Membolos Peserta Didik Kelas VIII MTs Miftahul Ulum Merabung Iii Kecamatan Pugung Kabupaten Tanggamus. KONSELI: Jurnal Bimbingan Dan Konseling (E-Journal), 3(1), 19-28.

Fandini, P., Sulatani, S., \& Susanto, D. (2018). LAYANAN KONSELING KELOMPOK DENGAN TEKNIK BEHAVIORAL CONTRACT DALAM MENUMBUHKAN KARAKTER DISIPLIN SISWA DI SMA PGRI 2 BANJARMASIN TAHUN

AJARAN2017/2018. Jurnal Mahasiswa BK An-Nur: Berbeda, Bermakna, Mulia, 4(1), 13-20.

Fiara, A., Nurhasanah, N., \& Bustamam, N. (2019). Analisis faktor penyebab perilaku tidak disiplin pada siswa SMP Negeri 3 Banda Aceh. JIMBK: Jurnal Ilmiah Mahasiswa Bimbingan \& Konseling, 4(1).

Haq, M. D. D. (2019). PERAN GURU BK DALAM MENANGANI PRILAKU
MEMBOLOS SISWA DI MTs NU RAUDLATUS

SHIBYAN. KONSELING EDUKASIJournal of Guidance and Counseling, 3(2).

Islami, J. (2020). HUBUNGAN ANTARA KECEMASAN SOSIAL DAN PRIBADI INTROVERT DENGAN AKTUALISASI DIRI PADA SISWA KELAS VIII DI SMP NEGERI 13 BANJARMASIN. Jurnal Pelayanan Bimbingan Dan Konseling, 1(2).

Jaelani, A. Q., \& Ilham, L. (2019). Strategi Meningkatkan Kecerdasan Emosional dan Spiritual Siswa. KOMUNIKA: Jurnal Dakwah Dan Komunikasi, 13(1), 97-106.

Jolivette, K., Swoszowski, N. C., Sanders, S., Ennis, R. P., \& Boden, L. J. (2018). Positive Behavior Agreements. Journal of Correctional Education (1974-), 69(3), 16-31.

Khadijah, K., Marjohan, M., \& Bentri, A. (2016). Kontribusi dukungan orangtua dan persepsi siswa tentang disiplin belajar terhadap perilaku membolos serta implikasinya terhadap layanan bimbingan dan konseling. Konselor, 5(3), 172-181.

Komalasari, G., \& Wahyuni, E. (2011). Teori dan teknik konseling. Jakarta: Indeks.

Majeika, C. E., Wilkinson, S., \& Kumm, S. (2020). Supporting Student Behavior Through Behavioral Contracting. TEACHING Exceptional Children, 40059920952475.

Marisa, C., Fitriyanti, E., \& Utami, S. (2018). Hubungan pola asuh orangtua dengan motivasi belajar remaja. Jurnal Konseling Dan Pendidikan, 6(1), 25.

Marisa, C., \& Putri, A. M. (2017). The influence of individual counseling in improving learning motivation for 
students. TERAPUTIK: Jurnal Bimbingan Dan Konseling, 1(2), 137-144.

MASYITHAH, M., Nurhasanah, N., \& Nurdin, S. (2019). ANALISIS FAKTOR-FAKTOR PENYEBAB SISWA MEMBOLOS SEKOLAH di SMP NEGERI 16 BANDA ACEH. JIMBK: Jurnal Ilmiah Mahasiswa Bimbingan \& Konseling, 4(3).

McKinney, S. (2013). Truancy: A research brief. New York, NY: Vera Institute of Justice, Status Offense Resource Centre.

Nwokolo, C., Anyamene, A., \& Nzerem, H. O. P. (2020). Relative Effectiveness of Cognitive Restructuring and Contingency Contracting Techniques on Bullying Behaviour Among Secondary School Students in Imo State. Journal of Guidance, 4(2), 114-124.

Obibuba, I. M. (2020). Behaviour Modification as An Effective Technique in Classroom Teaching. Behaviour, 10(12).

PARAMITA, F. C. (2017). Penerapan Konseling Behavioristik Dengan Teknik Behaviour Contract Untuk Mengatasi Siswa Yang Sering Terlambat Sekolah Di Smk Wisudha Karya Kudus Tahun Pelajaran 2016/2017. UMK.

Prabowo, A. (2016). Kesejahteraan psikologis remaja di sekolah. Jurnal Ilmiah Psikologi Terapan, 4(2), 246260.

Prayitno. (2018). Konseling Profesional yang Berhasil. Depok: RajaGrafindo Persada.

Prayitno, E. A., \& Amti, E. (2004). DasarDasar Bimbingan dan Konseling. Jakarta: Rineka Cipta.

PURNAMASARI, W., \& MUIS, T. (2018). STUDI KASUS TENTANG PERILAKU MEMBOLOS SISWA
DI SMA NEGERI 1 PLUMPANG TUBAN. Jurnal BK UNESA, 9(1).

Putri, L. R. (2017). Pengaruh Konformitas Teman Sebaya Terhadap Perilaku Membolos Pada Remaja SMKN 10 Semarang. Universitas Negeri Semarang.

Putri, W. S. R., Nurwati, N., \& Budiarti, M. (2016). Pengaruh media sosial terhadap perilaku remaja. Prosiding Penelitian Dan Pengabdian Kepada Masyarakat, 3(1).

Rahmadhony, S. (2019). The Effectiveness of Token Economy to Reduce Truant Behaviour. International Journal of Education \& Curriculum Application, 2(1), 24-30.

Reswastiyo, A., \& Rahmi, S. (2019). PENGARUH TEKNIK BEHAVIOR CONTRACT TERHADAP DISIPLIN BELAJAR SISWA KELAS VIII SMP N 6 TARAKAN TAHUN PELAJARAN 2018/2019. Jurnal Bimbingan Dan Konseling Borneo, 1(1).

Sanyata, S. (2012). Teori dan aplikasi pendekatan behavioristik dalam konseling. Jurnal Paradigma, 14(7), $1-11$.

Setyowati, P., \& INDAH PRATIWI, T. (2019). PENERAPAN KONSELING KELOMPOK PENDEKATAN SOLUTIONFOCUSED BRIEF THERAPY (SFBT) UNTUK MENGURANGI PERILAKU MEMBOLOS SISWA DI SMPN 33 SURABAYA. Jurnal BK UNESA, 9(3).

Sitorus, M. (2020). Studi tentang Pemanfaatan Waktu Siswa Membolos pada Siswa Kelas X di Sekolah Menengah Kejuruan Telekomunikasi Pekanbaru. UNIVERSITAS ISLAM NEGERI SULTAN SYARIF KASIM RIAU.

Sulistyawati, S., \& Hudaya, A. (2018). KONSELING INDIVIDU 
Jurnal Inovasi BK,Volume 2, Nomor 2 Desember 2020

DENGAN TEKNIK BEHAVIOR

CONTRACT DALAM

MEMINIMALISIR PERILAKU

MALADAPTIF ANAK DI BALAI

PEMASYARAKATAN (BAPAS)

KLAS II SURAKARTA. IAIN

SURAKARTA.

TRI MURDIANTI, Y., \& Nursalim, M.

(2018). Studi Tentang Perilaku

Membolos Siswa di SMP Negeri 2

Semen Puhsarang Kabupaten

Kediri. Jurnal BK UNESA, 9(1).

Wahyuningrum, N. (2019). FAKTOR-

FAKTOR PENYEBAB PERILAKU

MEMBOLOS SISWA DI SMK

NEGERI 9 SURAKARTA.

Universitas Negeri Semarang.

Yulianthi, H., Komalasari, G., \& Mamesah, M. (2012). Faktor Penyebab Siswa Membolos (Survey pada Siswa Kelas VIII SMP Negeri 232 Jakarta). INSIGHT: Jurnal Bimbingan Konseling, 1(2), 3-6. 